\title{
Nietzsche's Questions Concerning the Will to Truth
}

\author{
SCOTT JENKINS*
}

FRIEDRICH NIETZSCHE WAS FASCINATED BY our tendency to attach overriding importance to the project of gaining knowledge, and discussions of the "will to truth" occupy center stage in his later philosophy. Beyond Good and Evil opens with two questions concerning the will to truth, On the Genealogy of Morals ends with an account of its connection with morality, and the second edition of The Gay Science includes a fifth book that presents the death of God as a problem we can grasp only by appreciating Nietzsche's account of our will to truth. Most commentators have assumed that Nietzsche devotes so much attention to the will to truth because he takes it to be objectionable and seeks to make its objectionable features clear

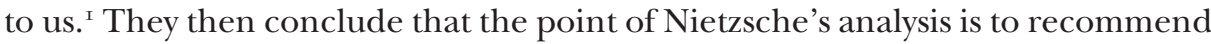
to us a particular position on the value of truth, perhaps one that would justify an orientation toward the truth different from the will to truth. Here I argue that Nietzsche's own views on the value of truth do not follow from his critique of the will to truth. While his analysis of the will to truth does establish that our present commitment to the truth is both unstable and part of a distinctively moral life, I show that he does not take these facts alone to determine the value of a will to truth in general. In fact, in his discussions of the will to truth Nietzsche ultimately aims to make the much more general point that we atheists and "immoralists" presently lack the ability to determine the value of any value whatsoever. Thus $\mathrm{Ni}$ etzsche's critique of the will to truth establishes both more and less than is usually thought-more, because it demonstrates our need for a standard to be employed

${ }^{\text {I}}$ Works that take Nietzsche's analysis to justify a negative attitude toward the will to truth include the following: Ken Gemes, "Nietzsche's Critique of Truth"; Ken Gemes, "Strangers"; Brian Leiter, Nietzsche on Morality; Simon May, Nietzsche's Ethics and his War on "Morality"; Peter Poellner, Nietzsche and Metaphysics; Bernard Reginster, "What is a Free Spirit?"; Aaron Ridley, Nietzsche's Conscience. Works that take Nietzsche's analysis of the will to truth to yield a positive assessment of its value include the following: Randall Havas, Nietzsche's Genealogy; Walter Kaufmann, Nietzsche: Philosopher, Psychologist, Antichrist. The work closest to my position is Maudemarie Clark's Nietzsche on Truth and Philosophy. Clark maintains that we cannot currently judge the value of truth, and that Nietzsche's analysis does not entail a rejection of the will to truth. Our routes to this result are quite different, as I note in what follows.

\footnotetext{
* Scott Jenkins is Assistant Professor of Philosophy at the University of Kansas.
}

Journal of the History of Philosophy, vol. 50, no. 2 (2012) 265-289 
in a revaluation of values, and less, because it does not determine whether, or in what way, a person ought to pursue the truth.

My discussion is oriented around the two questions that open Beyond Good and Evil-first, "What in us really wants "truth'?” and second, "Why not rather untruth? and uncertainty? even ignorance?" (BGE I). ${ }^{2}$ The first question concerns the psychological ground of our present commitment to the truth, and this is a question to which Nietzsche's writings provide an answer. The second asks for a justification for this kind of truthfulness. ${ }^{3}$ I argue that it is only by recognizing that Nietzsche's critical account of our will to truth does not suggest even a provisional answer to this question that we can understand why Nietzsche takes his engagement with the will to truth to be of such importance.

I begin in section I by examining the question of what Nietzsche means to designate with his talk of 'will to truth.' Since my position on Nietzsche's attitude toward the will to truth differs from the received view, one might suspect that what I take Nietzsche to mean by this phrase is different from what others take him to mean. While I do depart from most readers in taking the will to truth to involve no substantive position on the nature of truth, I aim to show through appeal to Nietzsche's use of 'will to truth' and related terminology that my approach is the correct one. The importance of the philosophical issues that arise from my approach, and their relevance for other aspects of Nietzsche's work, will further confirm the understanding of the will to truth outlined here. Section 2 considers Nietzsche's remarks on cognition and his best-known discussion of the will to truth $\left(G S_{344}\right)$. Here I show that Nietzsche sees no easy answer to the question Why not rather untruth? - and that he appeals to this difficulty in motivating a counterintuitive answer to the question What in us wants truth? I argue that Nietzsche regards the will to truth as a moral commitment insofar as it currently has the same function in a human life as Christian ascetic commitments, that of providing a particular kind of relief from the anxiety we feel in the face of the meaninglessness of human suffering. In section 3 I argue that Nietzsche's notions of the end of morality and the death of God, as well as their importance for the modern intellectual, come into focus only once we see that Nietzsche takes the question Why not rather untruth? to admit of no easy answer. I conclude by explaining how Nietzsche's project of the revaluation of values arises from his critique of the will to truth.

\section{TH RE C C O P O N EN T S OF TH E W I L L T O T R U TH}

In light of the significance that Nietzsche accords to his questioning of the will to truth, it is surprising that the extensive literature on the later philosophy does not exhibit any agreement on the issue of what Nietzsche means by "will to truth."4

${ }^{2}$ Nietzsche's works will be cited within the text using the abbreviations listed in the bibliography. In those cases where I depart from the translations listed in the bibliography, I supply Nietzsche's German in square brackets.

II will use the term 'truthfulness' to pick out any active orientation toward the truth. The will to truth, as described in sect. I below, is thus a species of truthfulness.

${ }^{4}$ The will to truth is sometimes characterized as a desire (see Poellner, Nietzsche and Metaphysics, IO8) and sometimes as a belief-like, cognitive state (see Reginster, "What is a Free Spirit?", 68-69). Commentators also diverge on the question of what notion of truth, if any, is a component of the will to truth. 
This lack of agreement - which is itself rarely noted-has made it difficult for there to be any progress in our understanding of this central topic in Nietzsche's work. Thus I begin with an account of the phenomenon that Nietzsche has in mind.

The will to truth, sometimes termed the "will to knowledge" (BGE 6), contains three components. First there is an element governing belief formation and retention that goes by a number of different names in Nietzsche's writings, including "intellectual honesty" ( $A$ I 2 ), "integrity in matters of the spirit" ( $\left.A_{5} \mathrm{O}\right)$, and "intellectual conscience" ( $G S$ 2; GS 335; GM III.24). Very roughly, these terms pick out a commitment to believing in accordance with evidence and argument. Nietzsche defines the intellectual conscience, for example, as a refusal to "believe this or that and to live accordingly without first becoming aware of the final and most certain reasons pro and con" $\left(G S_{2}\right) .5$ One might think of the intellectual conscience as a commitment to believing $p$ only when we possess excellent evidence of the truth of $p$. And by 'excellent evidence,' Nietzsche has in mind the following criteria. First, our evidence must encompass considerations both for and against the truth of $p$ (as he puts it, both pro and con). Second, our evidence on both sides must be relatively complete, yielding reasons for belief that are "final and most certain." And third, our evidence must, whenever possible, be collected prior to believing $p$ and living our lives in accordance with that belief.

These criteria for goodness of evidence, and thus for goodness of belief, are undoubtedly reasonable and have some respectable consequences. Considered as rules guiding one's cognitive life, however, these criteria are also quite obviously insufficient and underspecified, in part because Nietzsche, in his frequent demands for genealogy or good philology, recognizes the difficulty of making explicit the norms that ought to govern "scientific" work in a particular field of knowledge (GMI.I; A 52; etc.). But more importantly for my purposes, Nietzsche proposes just these criteria as marks of intellectual integrity because he sees them as correctives for intellectual tendencies that take us further from the truth, many of which take the general form of wishful thinking. ${ }^{6}$ These three criteria are not meant as a complete specification of proper thought, but rather as general schemata for rules that will interact with our cognitive tendencies in such a way that we will likely come to believe the truth.

Looking at intellectual conscience in this manner makes Nietzsche's list of criteria look a little less arbitrary. Throughout his later philosophy he maintains that while we often believe in accordance with the evidence, we possess many of our beliefs because they give us a feeling of pleasure, security, or self-respect-not

${ }^{5}$ Nietzsche's talk of reasons is meant to pick out empirical evidence as well as rational argument. In $G S 2$ he emphasizes reason, describing "pious persons" as possessing a "hatred of reason." In other contexts Nietzsche stresses the importance of empirical evidence for the construction of theories of any kind. This emphasis is especially clear in his late praise of the senses (TI III), and of the "hard factuality" of Thucydides's practice of history (see Jenkins, "What Does Nietzsche Owe Thucydides?", 42-45). Nietzsche never constructs anything resembling a theory of evidence, however, and the question of what, exactly, he takes to be good evidence lies outside my scope here.

${ }^{6}$ Other intellectual tendencies also serve to separate us from the truth. For example, Nietzsche identifies in us a tendency to fall victim to a "seduction of language" in our theorizing ( $G M$ I.I 3 ; BGE I7). The detection and minimization of these additional impediments would require the activity of the intellectual conscience. 
because they are supported by the evidence (GMI.I 3 ; GS I IO; $A 50 ; A 5$ I; etc.). In the case of beliefs that bring with them significant benefits, our possession of those beliefs is almost completely independent of the evidence we have for or against them. Our worldview is thus composed, at least in part, of what Nietzsche terms "untruths"-firmly-held beliefs for which our evidence is radically inadequate. ${ }^{7}$ Such untruths themselves shape our tendency to form and evaluate new beliefs, and the prevalence and utility of such beliefs underlies Nietzsche's assertion that untruth is a "condition of life" $\left(B G E_{4}\right)$. The intellectual conscience, which requires us to collect evidence prior to believing this or that $\left(G S_{2}\right)$, thus serves to limit the influence of untruth on our belief structure. ${ }^{8}$

Of course, Nietzsche does not think that it is always possible to engage in the process of gathering and evaluating evidence prior to living in accordance with a belief. We always find ourselves with all kinds of beliefs, and we clearly need to evaluate those beliefs as well in order to discover how many of them are untruths, or mere convictions. Accordingly, we might regard the intellectual conscience as requiring us to engage in the activity of examining old beliefs and potential new beliefs through attending to the evidence using the best techniques at our disposal. Such activity resembles the "skepticism" that Nietzsche praises in his character Zarathustra, who is said to aim at freeing himself from the influence of mere convictions $(A 54)$. This freedom need not involve completely rejecting a belief, and Nietzsche emphasizes that his "philosophers of the future" will possess cognitive states between belief and unbelief, thereby trafficking in "dangerous Maybes" ( $B G E 2)$. To possess an intellectual conscience with respect to some matter is, therefore, to vary one's degree of belief appropriately in response to the evidence, thus modifying one's belief structure in a manner that limits, to the greatest extent possible, the influence of our tendency toward wishful thinking.

That the intellectual conscience is an essential component of the will to truth is clear from Nietzsche's characterization of modern intellectuals possessing a will to truth as "these last idealists of knowledge in whom alone the intellectual conscience dwells and is incarnate today" (GM III.24). Such conscientiousness forms the core of the will to truth, but the problems concerning truthfulness that interest Nietzsche arise only in conjunction with two further qualities. The will to truth is also unlimited in scope, in the sense that the intellectual conscience is to

${ }^{7}$ Nietzsche does not provide a definition of 'untruth' (Unwahrheit), but this understanding fits the texts quite well. Nietzsche uses the term in roughly the same way he uses 'conviction' (Überzeugung, GS $344 ; A 54$ ) or even 'mere appearance' (Schein, $B G E_{34}$ ). In some contexts untruths do appear to be cases of falsification $\left(B G E_{4}\right)$ or deception $\left(B G E_{34} ; G S_{344}\right)$, but in these contexts Nietzsche is likely relying on the further claim, formulated elsewhere, that strongly held beliefs unsupported by the evidence are almost certainly false ( GM III.24; $A$ 50). It is not in virtue of being false that a belief is an untruth.

${ }^{8} \mathrm{Nietzsche}$ also diagnoses in us a tendency to obscure these facts about our most cherished beliefs through raising wishful thinking to a principle of belief formation or a criterion of truth, which yields a satisfaction in taking oneself to know the truth that is divorced from the unpleasantness associated with actually being in touch with the truth. His favorite example of this phenomenon is the Christian "proof of strength," according to which the feeling of comfort or pleasure that we acquire upon believing $p$ is taken to be conclusive evidence of the truth of $p$ ( $A$ 50; GM III.24). Nietzsche also sees this tendency in Kant's notion of practical reason, which he describes as "a special kind of reason for cases in which one need not bother about reason" ( $A_{\text {I } 2}$ ). Reginster provides an excellent discussion of this strand in Nietzsche's thinking (Reginster, "What is a Free Spirit?", 59-6I). 
govern the formation and retention of beliefs in every sphere of life. This second mark of the will to truth is evident in Nietzsche's question, "Wouldn't the cultivation of the scientific spirit begin when one permitted oneself no more convictions?" ( $G S 344$, emphasis added). As a matter of fact, however, the will to truth has its greatest effect in relation to two classes of belief: metaphysical or distinctively religious beliefs (which it often reveals as unsupported by evidence or argument), and beliefs in moral psychology (which Nietzsche sees as incompatible with his own observations and theories). This focus results from our great need, in these spheres of belief, to view the world in a particular way regardless of what evidence we have for our beliefs. Because of this need there exists a tendency to limit one's concern with truth to spheres in which being conscientious about evidence rarely generates threats to beliefs that are important to us. Nietzsche diagnoses such a tendency in many "scholars" who admire themselves for their commitment to the truth while they, at the same time, limit the scope of their intellectual conscience to a rather narrow range ( $B G E 6$; GM III.23). Such a tendency is personified in Thus Spoke Zarathustra in the figure who calls himself the "conscientious in spirit" (Z IV.4). This rather pathetic character, who limits his conscientiousness to the brain of the leech (at the expense of the rest of the leech, not to mention the rest of the world around him) respects himself as one willing to sacrifice for the truth, while avoiding the painful effects of sacrificing desirability to truth in other areas of his life.

The third mark of the will to truth is found in its relation to other commitments a subject may have. Nietzsche characterizes the will to truth and those who live in accordance with this will as "unconditional" as a way of indicating the supremacy of this commitment in relation to others ( $G S_{344}$; GM III.24). The will to truth requires that we believe in accordance with the evidence regardless of what other goods might be sacrificed as a result-that we "sacrifice all desirability to truth" (GM I.I). This thought can be more accurately expressed using the notion of overridingness. In explaining what he means by the unconditional nature of the will to truth, for example, Nietzsche asserts that the will to truth rests on the conviction that "Nothing is more necessary than truth; and in relation to it, everything else has only second-rate value [ hat ... einen Wert zweiten Rangs]" (GS 344$)$ —surely an expression of the overriding value of true belief. Nietzsche's thought is not that the will to truth always generates some reason for action, but that reasons grounded in this commitment are the more authoritative reasons regardless of context. ${ }^{9}$ While it is certainly possible to imagine a lesser truthfulness that is not overriding, just as it is possible to imagine a truthfulness limited in scope, when Nietzsche uses the phrase 'will to truth' to pick out the truthfulness of modern intellectuals, it is always this stringent commitment that he has in mind ( $G S_{344}$; GM III.24; GM III.27).

${ }^{9}$ Nietzsche is not consistent in using 'unconditional' (unbedingt) to designate overridingness. At times he has in mind the thought that the will to truth is commonly regarded as applying to all persons, regardless of their contingent motivational state. In sect. 3 I argue that Nietzsche in fact distinguishes between this latter notion-the thought that this sort of truthfulness is a duty-and the overridingness that characterizes this sort of truthfulness. 
Summing up these three points, we can define the will to truth as an overriding commitment, unlimited in scope, to believing in accordance with evidence and argument. Because the will to truth as a matter of fact has its greatest effect when applied to beliefs that are metaphysical, religious, or ethical, we might understand it simply as an overriding commitment to knowing the truth about those aspects of our lives that affect us most deeply. The will to truth lies behind all activities that Nietzsche praises as Wissenschaft, including respectable work in fields such as philology and history, but the case of the philosopher interests Nietzsche the most. The philosopher, after all, appears most conscientious about questioning deeply-held beliefs, regardless of which other goods must be sacrificed as a result.

\section{I.I Truthfulness Without Truth?}

It may seem that in outlining Nietzsche's notion of the will to truth I have left out one essential element, namely a commitment to the existence of the truth. And it might be thought that this element provides a good reason to think that Nietzsche finds the will to truth objectionable. After all, in Twilight of the Idols Nietzsche famously proclaims that the idea of a "true world" has finally been recognized as "an error" (TI IV). In the Nachlass he goes even further, occasionally asserting that there are no facts, or that every claim is false. If Nietzsche were to maintain that there is no truth, the will to truth would clearly be open to one sort of criticism. A will to $x$ is at the very least unhealthy if $x$ does not exist, or cannot be realized. Fortunately, Nietzsche does not hold the inconsistent position that no claim is true. ${ }^{10}$ Throughout the published writings he flags individual claims as true and false. He also explicitly affirms the existence of truth in the Genealogy by concluding his praise of a commitment to "sacrifice all desirability to truth, every truth, even plain, harsh, ugly, repellent, unchristian, immoral truth," with the remark "[f] or such truths do exist-" (GM I.I). Because Nietzsche proclaims that there are such truths, he must believe both that truth is obtainable for beings with our cognitive capacities and that we are sometimes entitled to claim that a belief is true. Thus Nietzsche must hold that in some cases the heightened attention to evidence and argument characteristic of the intellectual conscience results in a true belief. Nietzsche could not be opposed to the will to truth on the grounds that there is no truth.

It could be, however, that Nietzsche regards the will to truth as involving a particular understanding of the nature of truth, such as the strong metaphysical realism that he aims to capture through talk of a "true world." appear to identify the will to truth with belief in a "true world" in GS 344 (a passage I will discuss in detail below), where he asserts that "those who are truthful in that audacious and ultimate sense which faith in science presupposes thereby affirm another world than that of life, nature, and history." The remark strikes Nietzsche as

${ }^{10}$ Even in his late writings, Nietzsche does occasionally suggest that all thought or cognition involves falsification. But he also makes the various claims to truth I discuss here. For one way of reconciling these two commitments, see Anderson, "Nietzsche on Truth, Illusion, and Redemption," I 87-92.

${ }^{11}$ Poellner takes this position in identifying the will to truth with the desire for "metaphysical truth about what reality might be like 'in itself'" (Nietzsche and Metaphysics, I I2). 
so important that he repeats it in the Genealogy (GM III.24). In the latter context, however, Nietzsche's opposition to Christian "otherworldliness" does not lead directly to a negative assessment of the will to truth, as one would expect if the will to truth were, in part, a commitment to a "true world." Nietzsche simply asserts that "science itself henceforth requires justification" and that "there is a lacuna in every philosophy" (GMIII.24). In my analysis of $G S_{344}$ I will demonstrate that here again Nietzsche takes no stand on the second question of $B G E \mathrm{I}-$ Why not rather untruth?

While we could include in our description of the will to truth a fourth component of this will, namely a commitment to the existence of truth or the realizability of knowledge on some understanding of these notions, a commitment of this general sort is a part of any Nietzschean will. An account of the will to truth that is sensitive to Nietzsche's concerns with how we ought to understand truth or knowledge might even do away with talk of truth altogether. Pursuit of truth and pursuit of maximally justified belief look just the same, after all, and it is the origin and value of this activity that interests Nietzsche. Of course, a belief about the nature of truth could motivate one to engage in this activity. But Nietzsche's questions really are not about truth. They are about the distinctive activity produced by an intellectual conscience with unlimited scope and overriding authority. ${ }^{12}$

The final point to be made concerning the will to truth concerns its status as a Nietzschean will. This terminology captures the thought that we modern knowers simply find this orientation to the truth within ourselves. Independent of any principled reflection on the matter, we take the project of determining what is the case to be extremely important. Or to consider the point at the level of culture, the modern era accords the highest value to truth, as opposed to tradition, beauty, solidarity, etc. ( $G S$ I 23). Nietzsche assumes that this orientation to the truth must answer to some need in us, and his first question in $B G E$ I considers the nature of that need. In connection with what psychological state, he wonders, would a will to truth develop and grow? What in us wants truth? In considering the matter in this way, Nietzsche treats the will to truth as a subjective drive, the kind of thing that explains behavior. But he also considers the will to truth in a different manner-as a norm, or standard of behavior. This is how the will to truth appears to the modern subject who finds herself committed to the truth in this distinctive way. Her intention to pursue the truth at all costs is just one commitment among many possible and actual commitments and as such stands in need of some sort of justification. This is the point of view of Nietzsche's second question in BGE

\footnotetext{
${ }^{12}$ The question of whether anything turns on describing an activity as aiming at maximally justified belief or as aiming at truth lies at the center of the disagreement between deflationists and realists. For a classic deflationist denial that truth is a goal of inquiry, see Rorty, "Is Truth a Goal?", 289. On the other side of the debate, see Wright, Truth and Objectivity, I 2-24; and Horwich "The Value of Truth," 355 . It seems to me that this dispute reduces to the question of whether intentional activities are individuated by an agent's actual attitudes. If they are, and if we assume that a will to truth involves an intentional activity, then the activity produced by a will to truth is different from the activity produced by a will to maximally justified belief, even though these activities are indistinguishable to an outside observer. But it is not clear that Nietzsche would want to distinguish between these two activities. Nietzsche's taxonomy of the different notions of truth one might possess (TIIV; GM I.I; GS 344 ) seems independent of his understanding of the will to truth and the philosophical life it produces.
} 
I-Why not rather untruth? These two points of view on the will to truth appear in almost every discussion in Nietzsche's work, and one challenge for Nietzsche's reader is to determine whether he takes his remarks to bear on his first question, on his second question, or on both.

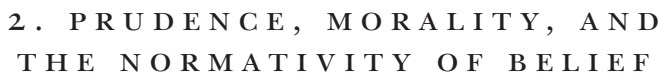

Nietzsche's discussions of the will to truth often shift back and forth between the two questions that concern him because he aims to motivate a counterintuitive account of the subjective ground of our truthfulness by demonstrating that we possess no easy answer to the normative question Why not rather untruth? In this section I show how Nietzsche's remarks on cognition and his best-known discussion of the will to truth in $G S 344$ serve to motivate his counterintuitive answer to the question What in us wants truth?

\section{I The Aim of Belief}

Even a very weak norm of truthfulness receives no support from Nietzsche's theory of cognition. Conscious thought or understanding is, he maintains, just a product of the wills and drives that constitute the existence of a living being: "It is only a certain behavior of the drives towards one another" (GS 333; see also BGE 36). This theory rests on the claim that our most basic relation to the world is through our drives, which interpret the environment in relation to their characteristic activity or interest. Our conscious thought is a refinement of these interpretations and thus is not fundamentally distinct from those conative entities. ${ }^{13}$ Exercises of thought that are especially successful in preserving or increasing the power of the organism's constituent drives are reinforced and held more and more firmly as their importance increases: "The strength of knowledge lies not in its degree of truth, but in its age, its embeddedness, its character as condition of life" ( $G S_{\text {I IO }}$ ). Beliefs that limit our efficacy through creating pain or despair are also quickly "forgotten" in order to preserve the health of the organism (GM II.I). The view here is not that our cognitive capacities yield to our needs, but that those capacities themselves create untruths by representing the world in whatever manner is responsive to our needs. While it certainly appears to us that many of the beliefs that shape our lives result from a process of rational reflection, Nietzsche maintains that in most cases those beliefs are to be explained through appeal to the autonomous activity of forces of which the believer is rarely if ever aware $\left(B G E_{3} ; B G E_{5}\right)$. Thus for Nietzsche, a belief is not the kind of thing that in its very nature ought to be true-even though a belief is, essentially, a state of taking-to-be-true. ${ }^{14}$ Because

\footnotetext{
${ }^{13}$ For an insightful account of Nietzsche's theory of the interpretive powers of drives, see Richardson, Nietzsche's System, ch. I.

${ }^{14}$ Here I disagree with Anderson, who states, "The practice of adopting beliefs because they make you happy or blessed is a worthy target of suspicion precisely because such 'motivated' or 'interested' believing aims at blessedness rather than truth-and potentially, or even typically, at the expense of truth. As the many related texts show, Nietzsche relies on the traditional assumption that cognitive judgment ought to aim at truth, even where truth violates our 'heart's desire' (BGE 229)" (Anderson,
} 
the function of a belief is to further the expression and expansion of a drive or set of drives, a belief considered merely as such is not open to criticism simply on the grounds that it is false. A false belief might be a good belief, provided that it supports a drive in this way.

Nietzsche's views on cognition underlie his interest in the psychological ground of the will to truth because they make a stringent norm of truthfulness appear strange and unnatural. Even the most basic "drive to truth," from which the modern will to truth originates, strikes Nietzsche as quite difficult to explain ( $G S_{\text {I IO }}$ ). This problem of accounting for any sort of truthfulness whatsoever dates back at least to Nietzsche's unpublished essay "On Truth and Lying in a Non-Moral Sense," where he remarks that "there is virtually nothing which defies understanding so much as the fact that an honest and pure drive towards truth should ever have emerged in [human beings]" (TLI). But we need not endorse Nietzsche's theory of cognition in order to appreciate the questions he asks concerning the will to truth. Even if we assume that cognitive systems have the singular function of representing an organism's environment, it does not immediately follow that the beliefs produced by such systems are constituted by a norm of truthfulness. ${ }^{15} \mathrm{~A}$ better argument for the normativity of belief might appeal to the need to distinguish between beliefs and other belief-like states, such as imagining, or assuming something for the sake of argument. Absent other means of distinguishing between these states, it would appear reasonable to maintain that beliefs, and only beliefs, by their very nature ought to be true. ${ }^{16}$ But notice how little this claim accomplishes in the context of Nietzsche's questions concerning the will to truth. If we assume that beliefs are required for action, and that a state is a belief only if it is a state of taking-to-be-true that also aims at the truth, then it follows that an agent is committed to getting at least some things right-and thus to being responsive to the evidence in these cases. But we still have no reason to think that such a commitment has overriding authority. Similarly, an Aristotelian position that identifies the drive to know as an essential feature of a human being provides no justification for the stringent norm of truthfulness that concerns Nietzsche.

\subsection{Gay Science 344-A First Glance}

Nietzsche begins his discussion in $G S_{344}$ with the question of how one might go about justifying this commitment. His topic is the activity of "science," intellectual activity governed by the will to truth-paradigmatically, his own work in philoso-

\footnotetext{
"Nietzsche on Truth, Illusion, and Redemption," I 88). The passages that Anderson cites in support of this claim are all characterizations of the will to truth, or of Nietzsche's own commitment to the truth. Thus Anderson confuses Nietzsche's position on the nature of a judgment with his characterization of a certain kind of concern with the truth. Anderson's view is also incompatible with Nietzsche's remark that "the falseness of a judgment is for us not necessarily an objection to a judgment" $(B G E 4)$.

${ }^{15}$ Dretske has argued that even if evolutionary history determines that cognitive systems have a proper function, there is no quick argument from here to the normativity of belief (Dretske, "Norms, History, and the Constitution of the Mental," 252). A view such as Dretske's leads directly to Nietzsche's questions concerning the psychological basis and justifiability of the norm that we tend to apply to belief.

${ }^{16}$ Velleman develops this position in detail. See "The Possibility of Practical Reason," 707-IO.
} 
phy. ${ }^{17}$ The question under consideration is initially the normative one, Why engage in science?-Why privilege knowledge in one's life?-Why not rather untruth?At first glance the argument of GS 344 appears rather simple in structure, as it turns on the claim that there are only two possible justifications for the will to truth-we aim at the truth either because we do not want to be deceived (that is, for prudential reasons) or because we do not want to deceive (that is, for moral reasons). These possible justifications are examined, and Nietzsche asserts that neither holds up to careful scrutiny. I will argue below that this appearance is deceiving, but it will be useful to begin with the surface structure of $G S 344$.

The prudential justification is dismissed rather quickly. Nietzsche suggests that because truth and untruth can both be useful, we must confront the question, "Is it really less harmful, dangerous, disastrous not to want to let oneself be deceived?" ( $G S_{344}$ ). He provides no examples of false beliefs (or likely-false untruths) that tend to produce practical benefits, but examples of such beliefs range from mundane cases to the comforting but false views about motivation that Nietzsche uncovers in the Genealogy. We do not need to agree with Nietzsche's views on cognition, or his famous claim that "untruth is a condition of life" $(B G E 4)$ in order to find it plausible that there exist useful deceptions. However, the conclusion that Nietzsche draws from the existence of beneficial untruths is rather surprising: "So, the faith in science, which after all undeniably exists, cannot owe its origin to such a calculus of utility; rather it must have originated in spite of the fact that the disutility and dangerousness of 'the will to truth' or 'truth at any price' is proved to it constantly" ( $G S 344)$. One might wonder why Nietzsche is drawing any conclusion whatsoever concerning the origin of the will to truth. His question, after all, concerns the ways in which this commitment might be justified. This surprising shift in focus might be explained by Nietzsche's desire to answer to the question What in us wants truth? As we will see, his answer to this question will appeal to our ascetic tendencies, and in this context the harmfulness of some truths can play a role in determining the origin of our will to truth. But a more pressing worry concerns Nietzsche's right to conclude that our faith in science did not originate in a calculus of utility. This conclusion would seem to follow only on the assumption that no one who had ever been harmed by the truth would, on prudential grounds, grant overriding force to the standard of believing in accordance with the evidence. ${ }^{18}$ As Nietzsche puts it, "Precisely this conviction [that truth is more

${ }^{17}$ Some commentators see a sharp division between the activity of a Nietzschean "scientist" and the activity of a philosopher such as Nietzsche (see Poellner, Nietzsche and Metaphysics, I I 2; Ridley, Nietzsche's Conscience, I I 6). Nietzsche's characterization of the problem of the will to truth as one relevant to "every philosophy," even the "most recent philosophers" (GM III.24), counts against this reading. More importantly, Nietzsche asserts that he knows the faith in truth "from too close up" (GM III.24) and consistently employs the first-person plural when discussing the problems faced by those who possess a will to truth ( $G S_{344}$; GM Pref. I; $B G E$ I; GM III.24; GM III.27; etc.). To be sure, Nietzsche's "philosopher of the future" also aims to create values, but for this task the scientific activity of knowing the "whither and for what of man" is said to be necessary (BGE 2I I).

${ }^{18}$ Reginster ("What is a Free Spirit?", 66) and Clark (Nietzsche on Truth and Philosophy, I86) both attribute this assumption to Nietzsche. As I argue below, even in GS 344 Nietzsche identifies a form of "faith in truth" that makes the will to truth appear prudent in the face of harmful truths and useful untruths. 
important than anything else] could never have originated if truth and untruth had constantly made it clear that they were both useful, as they are" (GS 344). But this assumption is unreasonable. For all Nietzsche has said, the will to truth could still be the cognitive norm justified by an appeal to prudence. At this point Nietzsche has shown only that an ideal cognitive state for an agent would likely involve a number of false beliefs. It could still be the case that the practice that gets one closest to that ideal state is precisely one of living in accordance with the will to truth. ${ }^{19}$ The rule believe all and only those propositions that it is beneficial for one to believe is not, after all, a rule that an agent can follow. An agent would have to gather evidence in order to determine which beliefs are the beneficial ones, and this process of gathering evidence would almost certainly leave the agent with beliefs that are harmful. ${ }^{20}$ And even if we were to assume that action in accordance with norms other than the will to truth takes one closer to that ideal cognitive state, Nietzsche's conclusion that the will to truth "cannot owe its origin to such a calculus of utility" would follow only if we ignore the possibility of miscalculation. But it is by no means obvious that the will to truth is not the norm that produces the optimal cognitive state for an agent. Thus we cannot rule out the possibility that agents would mistakenly adopt this cognitive rule on prudential grounds.

These considerations suggest that the first step in Nietzsche's argument in GS 344 is a failure. He apparently intends to demonstrate that our implicit justification for the will to truth is moral in nature-that in living in accordance with the will to truth "we stand on moral ground"-simply through showing that our justification could not be prudential. But the "disutility and dangerousness" of the will to truth does not follow from Nietzsche's claim that truth and untruth are both useful. And even if the will to truth were a less than optimal cognitive rule from the point of view of prudence, no conclusion concerning its origin or subjective ground would follow. What should we make of this apparent failure? While it may point to a genuine oversight on Nietzsche's part, I believe that by considering other claims concerning the will to truth in GS 344 and elsewhere it is possible to reconstruct a much more satisfying account of the problems associated with an appeal to prudence. Thus I will delay further examination of the prudential justification of the will to truth in order to consider the result that Nietzsche takes to follow from the alleged disutility of that commitment.

${ }^{19}$ The belief that the will to truth gets a person closest to an ideal cognitive state, or a social order closest to its ideal state, could give rise to respect for the will to truth in the face of the utility of some untruths or errors. Horwich endorses such an account of the origin of the belief that truth should be pursued for its own sake: "It is presumably because most truths are useful in practical inference-and not merely to those individuals who discover those truths, but also to all the rest of us to whom they are communicated-that our society, simplifying for the sake of effectiveness, inculcates a general concern for truth for its own sake" (Horwich, "The Value of Truth," 35I). While Nietzsche does not examine a view like Horwich's in his discussion of the will to truth, in his investigation into the origins of the morally good, Nietzsche dismisses an appeal to utility of just this sort (GM I.2).

${ }^{20}$ This is one reason why Nietzsche cannot simply recommend to us a truthfulness limited in scope or authority. It is impossible to describe such limits prior to coming to know the truth, and knowledge, once produced, is very difficult to eradicate. Those who see such a recommendation in Nietzsche's writings often focus on an agent's cognitive relationship to the past (see Anderson, "Nietzsche on Truth and Redemption," 203). But facts about the past, and knowledge of the past, are fixed in a way that the unknown future simply cannot be. 
The rather notorious conclusion that in possessing a will to truth we "stand on moral ground" is itself, at first glance, difficult to comprehend. The claim seems to be that the will to truth, and thus our entire modern intellectual or philosophical culture, is grounded on our recognition of the particular moral duty of not telling lies. ${ }^{2 \mathrm{I}}$ If this were so, the legitimacy of engaging in these scientific activities would stand or fall with the justification supplied for the moral duty of not deceiving. But this position would be bizarre-a point that is rarely made in the literature on Nietzsche's concern with truthfulness. We can appreciate this strangeness by noting that an account of the moral wrongness of deception, no matter how convincing, would hardly answer the worries of a person who wonders whether a life devoted to gaining knowledge about himself and the world around him is the kind of life he ought to be living. This moral duty must be construed as the requirement that we not intend to deceive others-and, possibly, ourselves-but the will to truth requires much more than this. It requires that we do everything in our power to prevent the creation or persistence of false beliefs in ourselves. While one should foresee that by choosing not to live up to the demands of the will to truth he would likely come to possess a number of false beliefs that he would not otherwise possess, and that he would likely pass those beliefs on to others, the requirement that one not intend to deceive would not be violated by such a choice.

The problem posed by the implausibility of the claim that the will to truth rests on the moral norm forbidding lying gives us reason to understand the alleged moral status of the will to truth through appeal to a different notion of the moral. Because Nietzsche takes his conclusion to follow directly from the claim that the will to truth cannot be understood as a form of prudence, he is regarding the will to truth as an instance of taking something to be valuable independent of its consequences. This could suggest to him that we are being scrupulous about evidence for its own sake, an attitude often regarded as a mark of the moral. People who take there to be a strict moral duty not to lie-Kantians, for example-regard lying as something to be avoided in virtue of its intrinsic nature. In other contexts this appears to be exactly what Nietzsche has in mind by the claim that the will to truth is moral: "Knowledge for its own sake'-that is the last snare of morality: with that one becomes completely entangled in it once more" (BGE 64). If we take Nietzsche's conclusion in $G S_{344}$ to consist of these two claims-that the will to truth is a matter of regarding truth as valuable for its own sake, and that such an attitude is a moral one-it can sound quite plausible. But such a reading also faces some serious obstacles. First, we would face the problematic conclusion that Nietzsche, contrary to his intentions, has given us little reason to be worried about our will to truth. After all, we could admit that this is an accurate description of the way in which we value the truth and still respond-So what? It is truth that we are valuing in this way, one might insist, not promise-keeping, the reduction of suffering, or whatever else. This approach to $G S 344$ would also leave mysterious why Nietzsche might flag the idea of knowledge for its own sake as the "last snare"

${ }^{21}$ Janaway endorses this reading, though he does not develop it in detail. See Janaway, Beyond Selflessness, 238. 
of morality (BGE 64). If the will to truth is moral simply because it is a matter of regarding something as worth pursuing for its own sake, it would seem that many other moral commitments would be possible for us.

\subsection{Otherworldly Asceticism}

Nietzsche's concluding remarks in GS 344 suggest a much more profitable approach to the moral nature of the will to truth. There Nietzsche ties "faith in science" to the affirmation of "another world than that of life, nature, and history" and also suggests that the will to truth could be "hostile to life," a "hidden will to death." Nietzsche thereby attributes to modern science the features he regards as defining marks of Christian morality-otherworldliness and asceticism. This attribution might seem to beg the question concerning the moral nature of science, though such an approach to $G S_{344}$ is, I believe, a misreading of the passage. Following his claim that by possessing a will to truth we stand on moral ground, Nietzsche continues, "For you have only to ask yourself carefully, 'Why do you not want to deceive?' especially if it should seem-and it does seem!- as if life aimed at semblance, i.e. error, deception, simulation, blinding, self-blinding" (GS 344 ). If we see this remark not as presupposing the conclusion that the will to truth is moral, but instead as offering us a reason to see it as moral, we can regard the remark as the beginning of an argument for the moral status of our will to truth. The suggestion would be that if we are pursuing the truth at the expense of life and the semblance that it involves, we must be taking something other than lifethat is, the maintenance and expansion of our drives-to be of value. But such a valuation is possible (the argument would run) only if we regard self-denial as valuable in itself or take there to exist something other than this world of life, semblance, etc. The burden would then be on Nietzsche to demonstrate that our will to truth is, in fact, ascetic and otherworldly in nature. His remarks in GS 344 are not sufficient to establish this point, which means that we must appeal to other texts in order to reconstruct Nietzsche's argument.

While I do not have the space necessary even to outline Nietzsche's account of the ascetic-otherworldly qualities of the will to truth in modern times, a brief summary of some central claims is enough for my purposes here. Living in accordance with the will to truth is ascetic, he asserts, because it requires at a minimum that one embrace the ideals of poverty, humility, and chastity as means for focusing the mind (GM III.8). The will to truth also requires a willingness to do without comforting beliefs for the sake of believing the truth. We must, for example, give up the thought that we occupy a privileged position in the great chain of being and embrace, instead, the view that we are just another part of nature (GM III.25; $B G E$ 230). At times we must practice the complete "abstinence" of withholding judgment on many matters that concern us, refusing "not only to affirm but also to deny" (GM III.24). Thus the philosopher not only does without the reassurance and security associated with possessing a complete, comforting worldview, but also abstains from the intellectual pleasure associated with taking oneself to have discovered the truth. Finally, the philosopher's overriding drive to know not only makes it difficult to satisfy other drives but actually damages and destabilizes 
those drives through destroying their foundations - "any insistence on profundity and thoroughness is a violation, a desire to hurt the basic will of the spirit which unceasingly strives for the apparent and superficial-in all desire to know there is a drop of cruelty" ( $B G E$ 229). In contrast to the case of the Christian ascetic, the philosopher's drive to inhibit other wills is rarely conscious, though Nietzsche insists that some philosophers do see in themselves a force that aims at retarding other drives $(B G E 230) .^{22}$

Just as distinctively religious asceticism makes sense to the practitioner largely through the postulation of a connection between that activity and a reward or lack of punishment, ascetic pursuit of the truth must appeal to some ultimate basis of the correctness of this activity. Nietzsche notes that like religious ascetics, many philosophers are inclined to believe a story involving unobservables according to which truth either possesses an exceedingly large amount of intrinsic value or serves as a means to goods with such value. Platonism and Christian theology are Nietzsche's favorite examples of otherworldly views of this sort. His argument in The Gay Science, for example, ends with the claim that we "we godless antimetaphysicians still take our fire, too, from the flame lit by the thousand-year old faith, the Christian faith which was also Plato's faith, that God is truth; that truth is divine" (GS 344). Regardless of whether knowing is regarded as a relation to forms illuminated by the Good, as an approach to the mind of God considered as the most real being, or as a means to attaining a life of eternal happiness, faith in Platonism or Christianity carries with it the thought that knowledge ought to be pursued at all costs. ${ }^{23}$

One might respond to Nietzsche's analysis by noting that most philosophers today are neither otherworldly nor proponents of asceticism. Very few are Platonists or strict Christians, after all. But Nietzsche need not deny this point, and in fact, this observation constitutes an essential part of the problem Nietzsche takes us to be facing in connection with our will to truth. His ultimate aim is to show that it is only within an otherworldly context that we can presently regard as reasonable the belief that the truth is worth obtaining "at any price" ( $G S 344)$, capable of redeeming any sacrifice.

At this point we can return to Nietzsche's examination of the prudential justification of the will to truth in $G S 344$. The essential point there is not that some false beliefs have been beneficial and some true ones harmful (though Nietzsche

${ }^{22}$ The claim that some philosophers engage in an activity that they know to be a kind of cruelty directed against themselves may strike us as one of the more implausible aspects of Nietzsche's account of the will to truth. In Nietzsche's defense, he states only that "every courageous thinker will recognize this in himself," and then only under certain conditions (BGE 230). And we should not read him as maintaining that such a person will see this activity as choiceworthy precisely because it is ascetic. Nietzsche suggests that a person who is not ashamed of the "merely" human could recognize and embrace cruelty as a distinctive feature of human existence ( $B G E 230 ; B G E 295)$. This is one reason why the tendency of the will to truth to create suffering by harming other drives does not count as conclusive evidence that it ought to be abandoned.

${ }^{23}$ Nietzsche usually expresses this point by claiming that there is a "metaphysical" element in our commitment to the truth, for example in his claim that our faith in science is a "metaphysical faith" $\left(G S_{344}\right)$ or that the will to truth has, so far, been "faith in a metaphysical value, the absolute value of truth" (GM III.24). 
certainly takes that to be the case), but that pursuing the truth at any cost can appear prudent only on the assumption that the world is ordered in such a way that knowledge will always, in the long run, enhance our lives. Nietzsche emphasizes that the prudential justification must regard science as a form of "long-range prudence [eine lange Klugheit]" because it is only by taking such a long-range view that the harmful effects of the will to truth can be discounted (GS 344). But to regard the will to truth-the most stringent norm of truthfulness-as prudent in the long run, we must believe that the world is ordered in accordance with our interests. More specifically, it must be ordered in such a way that the price we pay for coming to know the truth (such as the investment of other goods, the emotional trauma associated with unnerving discoveries, or the destabilization of our present values) will always appear, in retrospect, as lower in magnitude than the benefits that follow from knowing the truth (such as the acquisition of other goods, the attainment of psychic well-being, or the improvement in our acts of valuing themselves).${ }^{24}$ Of course, the world could be so ordered even if some of its features appear threatening or alien. So long as an increase in knowledge always carries with it, in the long run, a maximal improvement in our well-being-perhaps through enabling us to control or understand those features of reality-it would be the case that the world is ordered for our sake. That this is the case, however, receives no support from the evidence and argument at our disposal. ${ }^{25}$ Such faith in truth is, Nietzsche argues, a groundless remnant of a religious worldview, a mere "shadow of God" (GS I08). This is the point of Nietzsche's repeated assertion that "there is no pre-established harmony between the furthering of truth and the well-being of humanity" ( $H_{5}$ I $_{7}$; see also A 50; GM III.24). In keeping with the emphasis on faith and piety in The Gay Science, the point is phrased more cautiously there as the question, "[W] hat do you know in advance about the character of existence to be able to decide whether the greater advantage is on the side of the unconditionally distrustful or of the unconditionally trusting?" (GS 344). The suggestion, of course, is that only an otherworldly faith could lead one to believe that he knows something in advance concerning the long-term benefits of true belief. ${ }^{26}$

${ }^{24}$ The fact that action in accordance with our values can lead to changes in our values obviously adds complexity to this issue. I believe that Nietzsche's accounts of gay science and the process of experimentation show that he is aware of this issue, but I will not argue for that point here. For a brief account of this topic independent of Nietzsche's concerns, see Kitcher, "Truth or Consequences," 53-54.

${ }^{25}$ While Poellner emphasizes the implicit Platonism of the moral will to truth, he errs in regarding Nietzsche's assertion that God might "turn out to be our longest lie" ( $G S_{344}$ ) as one that is "highly problematic for Nietzsche to make" (Nietzsche and Metaphysics, I I 6). The thought that God exists is, for Nietzsche, not demonstrably false but instead an untruth-a belief for which we have radically insufficient evidence and argument. Accordingly, Nietzsche characterizes a preference for truth based on prudential considerations as involving "the worst proved assumption there is in the world" (BGE 34$)$.

${ }^{26}$ This thought may resonate even more at the social level, where it is not all clear that taking truth as our ultimate end is a way to preserve and improve a social order. In a remark that appears to engage with Nietzsche's doctrine of the eternal recurrence, Wittgenstein makes just this point: "The truly apocalyptic view of the world is that things do not repeat themselves. It isn't absurd, e.g., to believe that the age of science and technology is the beginning of the end for humanity; that the idea of great progress is a delusion, along with the idea that the truth will ultimately be known; that there is nothing good or desirable about scientific knowledge and that mankind, in seeking it, is falling into a trap. It is by no means obvious that this is not how things are" (Wittgenstein, Culture and Value, 56e). While Wittgenstein parts from Nietzsche in focusing on distinctively technological developments, his remark identifies a faith in truth of the sort that interests Nietzsche. 
Recognizing that asceticism and otherworldliness are the key elements in Nietzsche's argument for the moral nature of our will to truth reveals that the surface structure of $G S 344$ is somewhat misleading. ${ }^{27}$ While Nietzsche appears to be arguing that our implicit justification of the will to truth is moral because no one could regard it as grounded in prudence-a position that encounters two serious problems, as noted above-we should read him instead as claiming that regardless of whether we think that the truth possesses intrinsic value that swamps the value of other goods, or that the truth yields the greatest rewards in the long run, such an attitude toward the truth is just a remnant of an otherworldly doctrine. This is the approach suggested by his frequent remarks concerning an alleged pre-established harmony between truth and well-being, and furthermore, such an approach results in a much more interesting line of argument. Admittedly, Nietzsche does claim in GS 344 that the "disutility" of the will to truth should be obvious to all, which could suggest that he means to put forward the problematic argument concerning the origin of the will to truth identified above. But we can also understand this claim about disutility as intended to show that the long-term benefits of true belief are far from obvious. It is just this fact that points to an element of faith or piety in the person possessing a will to truth.

Thus Nietzsche's claim that "we, too, are still pious" is actually the principal conclusion of GS 344. We "stand on moral ground" by living in accordance with the will to truth insofar as the subjective ground of our truthfulness is the same kind of state found in the Christian, a state of faith that underwrites an ascetic way of life. This result provides a partial answer to Nietzsche's first question, What in us wants truth?

A more complete answer to this question must explain why we possess a faith of this sort. Nietzsche's account of faith is complex, but for my purposes it is sufficient to consider the role played by the universal horror vacui that Nietzsche postulates in the Genealogy. The third essay of that work opens with the remark, "That the ascetic ideal has meant so many things to humanity, however, is an expression of the basic fact of the human will, its horror vacui: it needs a goal-and it will rather will nothingness than not will" (GM III.I). This basic fact of the human will-that it experiences anxiety in the face of emptiness and is thus deeply averse to the thought our actions bear no relation to what is here provisionally characterized simply as a "goal" (Ziel)—grounds Nietzsche's explanation of moral asceticism and the ascetic, otherworldly characteristics of scientific life. His claim is that upon recognizing that our actions or experiences are meaningless, but inevitably accompanied by some degree of suffering, ${ }^{28}$ we as living beings always

${ }^{27}$ Readings that reconstruct Nietzsche's concerns by following the surface structure of GS 344 include Janaway's Beyond Selflessness, Reginster's "What is a Free Spirit?", and May's Nietzsche's Ethics and his War on "Morality."

${ }^{28}$ Recognizing that suffering is meaningless but unavoidable need not be a matter of bringing this fact to consciousness. Nietzsche's point is that it is exceedingly difficult-if not impossible-for us to face up to this fact. He attributes this recognition to the will in order to emphasize that he takes us to be oriented toward this fact in our practical activity, independent of any conscious reflection. Raymond Geuss argues for a similar role for the "wisdom of Silenus" in The Birth of Tragedy ("Introduction," xvii-xviii). 
aim to avoid not willing - that is, the state of "suicidal nihilism" in which we conclude that we, and the rest of the world, ought not to exist (GM III.28). ${ }^{29}$ Thus we must, Nietzsche thinks, come to take our actions to bear a relation to a goal that gives sense to our most unpleasant experiences through casting them as part of a project that itself has value. ${ }^{30} \mathrm{He}$ claims that while the Christian moral agent accomplishes this through faith in a doctrine of sin and redemption that explains the origin of suffering and promises that ascetic practices ensure passage into another world free of suffering, we seekers of knowledge limit anxiety through our complete devotion to the goal of truth (perhaps guided by the thought that knowledge will eliminate suffering $\left[B T_{14}\right]$ ). A number of metaphysical views fit this general model, including Schopenhauer's understanding of the ascetic life as the only one choiceworthy in light of the fact that the world in itself is nothing but will. Thus Nietzsche's accounts of Christian moral life, modern science, and Schopenhauerian asceticism present the metaphysical underpinnings of these ways of life as little more than projections of the "basic need" of the human will. The result is an inversion of Schopenhauerian metaphysics-our representations of the metaphysical world are explained through appeal to the horror vacui of the living, all-too-human will.

Nietzsche's account of this affinity between Christian morality, modern science, and Schopenhauerian asceticism stretches though the entire third essay of the Genealogy, but we need not consider the details of this account in order to appreciate its consequences for Nietzsche's first question concerning the will to truth. On this view, even the most respectable science or philosophy has simply served a practical purpose, or solved a practical problem. We have devoted ourselves to the truth in this distinctive way not because lacking knowledge is painful, because having it is pleasant, or because knowledge is a means to securing other goods, but because this commitment and its associated untrue beliefs have constituted the most effective way for us to deal with anxiety. In Beyond Good and Evil Nietzsche says of the "strange and insane task" of having knowledge, "[B] ut it is a task-who would deny that?" precisely in order to emphasize that what really matters for the seeker of knowledge is having a goal that appears to be justified by the world itself — any such goal—and not the actual end of coming to believe the truth (BGE 230). ${ }^{3 \mathrm{I}}$ Thus Nietzsche is maintaining that modern philosophers have not really been lovers of the truth. What we really want when we aim at truth is relief from anxiety, and the assumption that our will to truth is well-grounded yields this relief through enabling us to regard our lives and our suffering as having a sense (Sinn,

\footnotetext{
${ }^{29}$ Reginster provides a detailed account of this form of nihilism under the heading of "despair." See Reginster, The Affirmation of Life, ch. I.

${ }^{3}$ For further discussion of teleological explanations of suffering, see Williams, "Unbearable Suffering," 333-35.

${ }^{3}$ Poellner asserts that "the individual motivated by the 'will to truth' typically does not value the pursuit of the truth for its own sake, but its attainment" (Nietzsche and Metaphysics, I I 6). Reginster takes a similar position ("What is a Free Spirit?", 68). This view gains some support from the opposition between uncertainty and the will to truth that appears in Beyond Good and Evil (BGE I; BGE 24), but Nietzsche's psychological account of the truth-seeker in the Genealogy is not compatible with this view. See $B T$ I 5 for an early account of the relative importance of the activity of pursuing the truth, as well as an endorsement of Lessing's famous expression of a preference for pursuit of truth over its possession.
} 
GM II.7; GM III.28). Even though this pursuit of truth may appear "strange and insane" from some other point of view, we engage in this apparently endless task (which resembles the task of overcoming the "sinful" desires of the body) due to our supreme need for relief from our horror vacui. ${ }^{32}$

This claim concerning the function of our will to truth is the core of Nietzsche's charge that we "stand on moral ground" in privileging the truth in this distinctive way (GS 344). Thus Nietzsche's notion of the moral in this context is not primarily a substantive one, but rather a functional one. Moral commitments are those that alleviate anxiety through appearing to be grounded in a command that the world directs at us simply as human beings. In this way, they solve the practical problem that arises from our horror vacui by covering up or otherwise denying the goallessness of existence that induces anxiety.

While Nietzsche never defines the moral in exactly this manner-and obviously recognizes mere custom as a type of morality-it is just such an appearance of an end for existence that results in the demand for uniformity of behavior that Nietzsche often flags as a mark of the moral. In addition, only this functional notion of the moral makes sense of some of Nietzsche's most important characterizations of his concern with morality. In his I 886 preface to The Birth of Tragedy, for example, he asserts the most difficult question posed by the work is, "What, when seen through the prism of life, is the meaning of morality?" (BT Pref. 4). The Birth of Tragedy contains almost no mention of the central topics of the Genealogy, such as the values good and evil, the freedom of the will, and the bad conscience. But in its depiction of an inability to act once one has encountered in the "wisdom of Silenus" the thought that life is simply not worth living $\left(B T_{3} ; B T_{7}\right)$, it does identify a motivational problem similar to the one described in the Genealogy using the notion of horror vacui. The best way to read The Birth of Tragedy as posing questions about morality is to regard as moral any commitment that provides a certain sort of solution to this problem.

Nietzsche's ultimate objective in uncovering the moral nature of our will to truth is not merely to classify this drive as playing a particular role in our lives, but rather to reveal the instability of our project. This pursuit of truth produces a solution to our practical problem of dealing with anxiety only on the condition that we fail to provide the correct answer to the question What in us wants truth? This is the point of Nietzsche's proclamation that we are "unknown to ourselves, we knowers" and that we are "necessarily strangers to ourselves" (GMPref. I). But we cannot remain unknown to ourselves indefinitely. Such ignorance is a violation of our most basic value of truthfulness. The consequence of this instability is the end of morality itself.

\footnotetext{
${ }^{32}$ Gemes characterizes the ground of our truthfulness as "impotence and sublimated hostility" ("Strangers," I93) and as "fear of life and feelings of impotence" ("Strangers," I94). These are certainly reasonable expressions of Nietzsche's view, but they fail to identify the basic psychological force that unifies Nietzsche's account-horror vacui. As I argue in sect. 3, the importance of Nietzsche's questions concerning the will to truth comes into focus only once we recognize that it is a basic fact about the will that goallessness induces severe anxiety.
} 


\section{THE EN D OF MORALIT Y}

Just as the will to truth has led us to classify vast expanses of belief as mere faith or superstition-as Nietzsche puts it, "[S]laughtered one faith after another on this altar [of truth at any price]" (GS 344) -it has shown its own alleged justification to be just such an instance of untrue faith. Through calling itself into question in this way, the will to truth has, in Nietzsche's later philosophy, threatened its own authority. It is for this reason that Nietzsche emphasizes that he is telling us the truth about science (GM III.23) and characterizes his own work as a "lightning bolt of truth" (EH IV.8). As a result of this truthfulness, we must not only give up the remnants of Platonism or Christianity in our worldview that might provide a direct justification of an ascetic life. We must also embrace a new account of why we currently aim at truth in this distinctive way. And while we now recognize that aiming at the truth can serve to limit anxiety, given a proper context of faith, that moral truthfulness is no longer psychologically possible for us once that faith has been unmasked. This is because the pursuit of truth can limit anxiety only if an agent does not know that his pursuit of truth is playing this role in his life. Thus our understanding of what in us wants truth provides us with no response to Nietzsche's second question in BGE I, Why not rather untruth?

But does Nietzsche's account of the subjective ground of our truthfulness show that we ought not to live in accordance with the will to truth? It may appear that Nietzsche takes it to have this consequence. At the end of his discussion of the will to truth in the Genealogy, he asserts,

And here I again touch on my problem, on our problem, my unknown friends (for as yet I know of no friend): what meaning would our whole being possess if it were not this, that in us the will to truth becomes conscious of itself as a problem? As the will to truth thus gains self-consciousness-there can be no doubt of that-morality will gradually perish now. (GM III.27)

If we take the event of the will to truth gaining self-consciousness to be a matter of our realizing that it is unavoidably moral, this remark would indicate that Nietzsche takes his examination of the will to truth to be sufficient to demonstrate that we ought not to have such a commitment. The thought might be that we ought to give up this commitment because it ceases to appear as internally consistent. The will to truth would require both that we have an intellectual conscience and that we hold the kind of metaphysical view that would support our "faith in truth"either a Platonic commitment to the intrinsic value of truth, or a belief that the world has been designed in such a way that knowledge maximizes well-being in the long run. Nietzsche's denial of intrinsic value $\left(G S_{30 I}\right)$ and his rejection of a divine designer who gives a purpose to existence ( $G S_{\text {I }}$; $G S$ I09) would then commit him to regarding the will to truth as inconsistent.

The claim that Nietzsche finds the will to truth objectionable due to such an inconsistency appears to find support in his writings. In his first explicit discussion of these issues, he asks whether a "duty towards truth" is not a "contradiction" (Widersinn) in light of the fact that a thinker is committed to calling into question its status as a duty ( WS 43 ). In the Genealogy we also find a hint of this position: "This unconditional will to truth ... is the faith in a metaphysicalvalue, the intrinsic value 
of truth [Werth an sich der Wahrheit], sanctioned and guaranteed by this ideal alone (it stands or falls with this ideal)" (GMIII.24). In addition, the analysis of GS 344 begins with the question of whether the scientific drive to permit oneself no convictions itself rests on a conviction. And Nietzsche does, after all, conclude his examination of the will to truth in the Genealogy with the claim that "after Christian truthfulness has drawn one inference after another, it must end by drawing its most striking inference, its inference against itself" (GM III.27). Remarks such as these have led many readers of Nietzsche to believe that his examination of the will to truth yields the conclusion that we have erred in valuing the truth as we have. ${ }^{33}$

Such readings misrepresent Nietzsche's attitude toward the will to truth, thereby obscuring the importance of his questions concerning the will to truth in the context of his later work. The will to truth is inconsistent only if it requires that we take the truth to have overriding value and that we take it not to have overriding value. But such talk of the value of truth is ambiguous, as is the question of whether we should take the truth to have overriding value. On the one hand, this might be a question concerning the degree of value true belief possesses in itself. So understood it is a theoretical question, and Nietzsche's position on this issue is clear. On the other hand, the question of whether we should take truth to have overriding value can be understood as a concern with how we pursue the truth. A person who takes truth as her end and always prefers truth to other ends can be said to take truth to have overriding value in this second, practical sense. This, of course, is what is involved in having a will to truth. And if we ask whether Nietzsche thinks that such a person has made a mistake concerning the value of truth, we can only be asking whether he believes that another configuration of wills would be better for that person. ${ }^{34}$ This is a question that Nietzsche's critique of the will to truth never answers. ${ }^{35}$

${ }^{3}$ Reginster expresses this view most clearly in arguing that there is a "vicious paradox" here: "[T] he agent with a commitment to the unconditional value of truth cannot be a free spirit because, just by virtue of having this commitment, he fails to live up to it" ("What is a Free Spirit?", 69).

${ }^{34} \mathrm{Nietzsche}$ does not explicitly distinguish between these two ways in which one might take the truth to have value, which could give the impression that his talk of "the problem of the value of truth" ignores this distinction ( $B G E$ I; see also GS 344; GM III.24). Nevertheless, we ought to take the question that concerns Nietzsche to employ the second notion of taking the truth to have value, that of pursuing it in a particular manner. In light of Nietzsche's explicit assertion that nothing has value in itself ( $G S_{3}$ OI), it would be absurd to read him as asking, in the Genealogy, whether we should believe that the truth has value in itself. Furthermore, he terms the thought that "truth is inestimable and cannot be criticized" (GM III.25) - which plays exactly the same role as "faith in ... the intrinsic value of truth [Werth an sich der Wahrheit]" (GM III.24) - an "overestimation of truth" (GM III.25). Nietzsche clearly does not think that truth has value in itself, but he continues to assert that the will to truth requires justification, is just now becoming conscious of itself as a problem, etc. (GM III.27). Therefore the problem of the value of truth could only be the problem of determining whether, and in what way, a particular type of person ought to pursue the truth. I see no response to this problem in the Genealogy, and it seems to me that those who read Nietzsche as arguing that the will to truth involves an error concerning the value of truth conflate these two notions of valuing the truth. See for example Gemes, "Nietzsche's Critique of Truth," 47; May, Nietzsche's Ethics and his War on "Morality", I62; and Leiter, Nietzsche on Morality, 265.

${ }^{35}$ The ascetic qualities of the will to truth might suggest a valuation of the will to truth, but in the Genealogy even the ascetic ideal is not rejected in an unqualified manner: "All honor to the ascetic ideal insofar as it is honest!" (GM III.26). Nietzsche also admires some forms of asceticism (GM III.8). Finally, as I argue below, judging the value of a will to truth requires a standard of value that we presently lack. 
Nietzsche's claim that "morality will gradually perish now" can seem to commit him to a negative assessment of the will to truth only if we take the will to truth to be essentially moral. But recall that Nietzsche's characterization of this norm as moral is a claim concerning the role that truthfulness has played in our lives. The will to truth itself is simply a norm of conduct, or a conative state (depending on which of the two questions concerning the will to truth we are asking). The fact that it cannot be justified through appeal to traditional metaphysical views does not show that we have no reason to live in accordance with the will to truth. It shows only that we cannot regard this distinctive form of truthfulness as a duty. This is why Nietzsche emphasizes that Christian truthfulness must end by drawing an inference against itself (GM III.27), that it is a duty toward truth that he takes to be a contradiction (WS 43 ), and that faith in truth is an error (GS 344$).{ }^{36}$ Our will to truth has shown that it is not intellectually responsible to believe that some unobservable structure of the world justifies this pursuit of truth.

In addition, accepting Nietzsche's account of what in us wants truth would make it nearly impossible for us to regard any commitment as grounded in a command that the world directs at us simply as human beings. Understanding our will to truth as grounded in horror vacui forces us to regard with suspicion any claim that a particular commitment is a duty of this sort. We now know that belief in such duties is best explained by our need to overcome anxiety-and not by an ability to "hear" the commands the world directs at us as agents. Thus, the answer to Nietzsche's first question, What in us wants truth? leads directly to the conclusion that God is dead (as he prefers to express this point). The thought that our ways of life can be justified through appeal to a non-sensible structure of reality has become "unbelievable" ( $G S 343$ ) - no longer a live option for us-because of our understanding of why we modern intellectuals have continued in our will to truth. The idea of "knowledge for its own sake" thus serves as the "last snare" of morality ( $B G E$ 64) insofar as our recognition of its present status as a moral commitment grounded in anxiety ensures that no other commitment will be capable of playing this role in our lives.

So understood, the end of morality is not obviously a positive event. If we assume that it is, we completely miss the point of Nietzsche's critique of the will to truth. A positive attitude toward the end of morality might be justified through appeal to its status as an advance in our self-knowledge, but the end of morality has called into question our right to consider an advance in knowledge as progress. On the other hand, one might appeal to the liberating effect of this knowledge.

\footnotetext{
${ }^{36}$ The one passage that might appear to pose problems for my reading concerns the relation between "the unconditional will to truth" and the "ideal" that truth has intrinsic value-the former is said to be "sanctioned and guaranteed by this ideal alone (it stands or falls with this ideal)" (GM III.24). But if we understand by the unconditional will to truth a duty toward truth-that is, a commitment that applies to all persons unconditionally-then this passage is completely consistent with my approach. And Nietzsche does say that this unconditional will to truth constrains those who have it (Was aber zu ihm zwingt, GM III.24). It is unfortunate that Nietzsche uses 'unbedingt' sometimes to pick out overridingness, and sometimes to pick out interpersonal authority. In many contexts he aims precisely to emphasize that these notions can come apart, and that it is a sign of weakness to regard one's values as binding for all.
} 
But while Nietzsche undoubtedly believes that a more truthful understanding of many moral phenomena promotes the flourishing of stronger, higher, more capable human beings, he has no right to such optimism in this particular case. ${ }^{37}$ His examples of flourishing made possible through the debunking of morality and the identification of instances of false consciousness all presuppose the kind of psychological stability afforded by a solution to the practical problem of dealing with our horror vacui. The end of morality, however, brings with it the reemergence of that practical problem. It is for this reason that Nietzsche says of his questioning of the will to truth, " $[\mathrm{I}] \mathrm{t}$ does involve a risk, and perhaps there is none that is greater" (BGE I). That questioning has served to undermine our psychological stability, and it carries with it no hint of a new way of dealing with our horror vacui. Our realization that faith in truth is another shadow of God leaves us in a state of anxiety, confronting the emptiness of what Nietzsche terms "the horizon of the infinite" (GS I 24)..$^{8}$

Nietzsche's critique of the will to truth rather surprisingly yields no answer whatsoever to the question of whether, or in what manner, we ought to pursue the truth. The will to truth we find within ourselves is neither justified nor discredited, and it now shows up for us as a mere subjective drive. In addition, Nietzsche's own commitment to the truth (whatever that may be, the will to truth or some other norm) gains no support from the passages I have discussed. While Nietzsche states clearly that the ability to endure the truth is his "real measure of value" (EH Pref. 3 ) and that "the service of truth" requires "greatness of soul" ( $A_{5} \circ$; see also $A$ Pref.), any justification for these attitudes must lie elsewhere.

\section{I Values and Goals}

Nietzsche's ultimate concern in questioning our will to truth is much broader in scope than it might initially appear. This questioning brings into focus two different problems that Nietzsche takes us to be facing, whether we realize it or not. The first is the reemerging practical problem of dealing with our horror vacui. The second is the distinctively philosophical problem of determining how one might justify or discredit our present value of truthfulness independent of any appeal to the value possessed by an entity in itself $\left(G S_{3} O \mathrm{I}\right.$ ) or to a purpose for existence ( $G S$ I; $G S$ I09). I will conclude by sketching in very general terms what I take to be the common solution to these two problems suggested by Nietzsche's critique of the will to truth.

${ }^{37}$ Leiter (Nietzsche on Morality, 280-8I) and Gemes ("Strangers," 208) both take for granted that these revelations concerning our truthfulness will be beneficial, at least for some of us. Pippin presents a much more cautious approach to this issue ("Morality as Psychology," 359). Nietzsche himself might seem to present an optimistic account of the death of God in his characterization of its immediate consequences as "happiness, relief, amusement, encouragement, dawn" ( $\left.G S_{343}\right)$. But these immediate consequences fade in the following section.

${ }^{38}$ The image of the "horizon of the infinite" does not characterize the realm of the knowledgeseeker, as Reginster suggests, but instead depicts what remains for us once we realize that our truthfulness is groundless (Reginster, The Affirmation of Life, 236). While Nietzsche does connect this image with the philosopher's task at the end of $G S_{343}$, this remark serves to anticipate the argument in GS 344 that not even knowing can be regarded as a well-grounded commitment. Uncovering this "last snare" of morality does not merely result in a temporary disorientation, but rather leads us to the realization that "there is no more "land" that might provide an objective point of orientation (GS I 24). 
The second problem is evident in the Genealogy in Nietzsche's conclusion that there is no such thing as a presuppositionless science: "[A] philosophy, a 'faith,' must always be there first of all, so that science [Wissenschaft] can acquire from it a direction, a meaning [Sinn], a limit, a method, a right to exist" (GM III.24). The claim here concerns the activity of science itself. ${ }^{39}$ Following the end of morality, the task at hand is to consider whether the will to truth is supported by a "philosophy" that establishes its worth. As Nietzsche puts it, "[S]cience itself henceforth requires justification" (GM III.24). This remark, combined with his declaration that all philosophers are "oblivious of how much the will to truth itself first requires justification" (GM III.24), implores the reader to ask the question that most concerns Nietzsche-What could we possibly appeal to in order to provide a justification of the will to truth? This question quickly generalizes, becoming the much weightier question of how we might assess the value of any value. Such a new assessment of values, a revaluation of values, is made necessary by our realization that we at present have no reason to continue on in our will to truth, as well as no reason to give it up..$^{\circ}$ In these contexts Nietzsche does not attempt to describe the "philosophy" or second-order value that could serve as a principle for the revaluation-the value he elsewhere calls "power" or simply "life"-but he does encourage us to think of it as itself a goal. In the Genealogy he asks, "Where is the match of [the ascetic ideal]? Why has it not found its match?-Where is the other 'one goal [Eine Ziel]'?" (GM III.23; see also Z I.I 5, TI I.44, A I). The suggestion is that a new goal for humanity, one capable of inspiring us, can play the double role of providing some relief from our horror vacui and serving as a standard of value. Such a standard would be a starting point in answering a question such as Why not rather untruth? Thus Nietzsche's aim in questioning the value of truth is not to demonstrate that it possesses a particular value, but rather to lead us from this question to Zarathustra's proclamation that "the time has come for the human being to set itself a goal" ( $Z$ Pref. 5$) \cdot 4^{\text {I }}$

${ }^{39}$ In a recent edition of the Genealogy, Carol Diethe translates Nietzsche's phrase '"presuppositionless” science' ('voraussetzungslose' Wissenschaft) as ' "presuppositionless” knowledge,' and again translates 'Wissenschaft' as 'knowledge' later in the passage (GM III.24). See Nietzsche, "On the Genealogy of Morality" and Other Writings, I I 2. Diethe's mistranslation suggests that Nietzsche opposes the activity of science due to its reliance on a faulty conception of knowledge as presuppositionless. Relying on Diethe's translation, Leiter mistakenly concludes from this passage that "the overestimation of truth also involves an error about the nature of the truths we can actually know: it supposes, falsely, that our knowledge could be 'presuppositionless"” (Leiter, Nietzsche on Morality, 268). While Nietzsche's analysis in the Genealogy does, admittedly, identify a "general renunciation of all interpretation" as a species of asceticism (GM III.24), at no point in his analysis of science and the will to truth does he identify that will with a particular understanding of the nature of knowledge.

${ }^{4} \mathrm{Nietzsche}$ characterizes the essays of the Genealogy as "preliminary studies by a psychologist for a revaluation of all values" largely because the third essay demonstrates that the ascetic ideal "had no rival" (EHIII:GM). This remark is at least consistent with my claim that the ultimate aim of Nietzsche's engagement with the will to truth is to show that we need a new ideal that could serve as a principle of the revaluation. On this point I am in agreement with Clark (Nietzsche on Truth and Philosophy, 203). Our views differ, however, concerning importance of horror vacui for Nietzsche's analysis and the role played by the appeal to prudence (Clark, Nietzsche on Truth and Philosophy, I 83-84).

${ }^{4}$ Earlier versions of this paper were presented at Reed College, UC San Diego, UC Riverside, and the University of Kansas, and I am grateful to those audiences for their comments and questions. Two anonymous referees also offered valuable critical remarks. Finally, I have benefited from conversations with Steven Arkonovich, Eddie Cushman, Kevan Edwards, Mark Hinchliff, Paul Hovda, Michael Nelson, and Tom Tuozzo. 


\section{B I B L I O R A P H Y A D A B B REVIA T I O N}

I have employed parenthetical citations of Nietzsche's works using the abbreviations listed below. In those cases where I depart from the translations in these editions, I supply the German from Colli and Montinari's Sämtliche Werke: Kritische Studienausgabe (KSA).

A The Antichrist. Translated by Walter Kaufmann. In The Portable Nietzsche, edited by Walter Kaufmann, 568-656. New York: Penguin Books, I976.

BT The Birth of Tragedy. Edited by Raymond Geuss. Translated by Ronald Speirs. Cambridge: Cambridge University Press, I999.

BGE Beyond Good and Evil. Translated by Walter Kaufmann. New York: Vintage Books, I989.

EH Ecce Homo. Edited and translated by Walter Kaufmann. New York: Vintage Books, I989.

GM On the Genealogy of Morals. Translated by Walter Kaufmann. New York: Vintage Books, I989.

GS The Gay Science. Edited by Bernard Williams. Translated by Josefine Nauckhoff. Cambridge: Cambridge University Press, 200I.

HH Human, All Too Human. Edited by Richard Schacht. Translated by R. J. Hollingdale. Cambridge: Cambridge University Press, I996.

KSA Sämtliche Werke: Kritische Studienausgabe in I 5 Bänden. Edited by Giorgio Colli and Mazzino Montinari. Berlin: Walter de Gruyter, I980.

TI Twilight of the Idols. Translated by Walter Kaufmann. In The Portable Nietzsche, edited by Walter Kaufmann, 463-563. New York: Penguin Books, I976.

$T L \quad$ "On Truth and Lying in a Non-Moral Sense." In BT, I4 I-53.

WS The Wanderer and his Shadow. In HH, 30I-95.

Z Thus Spoke Zarathustra. Translated by Walter Kaufmann. In The Portable Nietzsche, edited by Walter Kaufmann, I03-439. New York: Penguin Books, I976.

Anderson, R. Lanier. "Nietzsche on Truth, Illusion, and Redemption." European Journal of Philosophy I3 (2005): I 85-225.

Clark, Maudemarie. Nietzsche on Truth and Philosophy. Cambridge: Cambridge University Press, I 990.

Dretske, Fred. "Norms, History, and the Constitution of the Mental." In Perception, Knowledge, and Belief, 242-58. Cambridge: Cambridge University Press, 2000.

Gemes, Ken. "Nietzsche's Critique of Truth." In Nietzsche, edited by John Richardson and Brian Leiter, 40-58. Oxford: Oxford University Press, 200I.

—. "We Remain of Necessity Strangers to Ourselves': The Key Message of Nietzsche's Genealogy." In Nietzsche's On the Genealogy of Morals: Critical Essays, edited by Christa Davis Acampora, I9I-208. Oxford: Oxford University Press, 2006. ["Strangers"]

Geuss, Raymond. Introduction to The Birth of Tragedy [BT], vii-xxx.

Havas, Randall. Nietzsche's Genealogy: Nihilism and the Will to Knowledge. Ithaca, NY: Cornell University Press, I995. [Nietzsche's Genealogy]

Horwich, Paul. "The Value of Truth." Nous 40 (2006): 347-60.

Hussain, Nadeem J. Z. "Nietzsche's Positivism." European Journal of Philosophy I 2 (2004): 326-68.

Janaway, Christopher. Beyond Selflessness: Reading Nietzsche's Genealogy. Oxford: Oxford University Press, 2007. [Beyond Selflessness]

Jenkins, Scott. "What Does Nietzsche Owe Thucydides?" Journal of Nietzsche Studies 42 (20 I I): 32-50.

Kaufmann, Walter. Nietzsche: Philosopher, Psychologist, Antichrist. Princeton, NJ: Princeton University Press, I974.

Kitcher, Philip. "Truth or Consequences." Proceedings and Addresses of the APA 72 (I998): 49-63.

Korsgaard, Christine. "Two Distinctions in Goodness." In Creating the Kingdom of Ends, 249-74. Cambridge: Cambridge University Press, I996.

Leiter, Brian. Nietzsche on Morality. London: Routledge, 2002.

May, Simon. Nietzsche's Ethics and his War on "Morality". Oxford: Oxford University Press, I999.

Nietzsche, Friedrich. "On the Genealogy of Morality" and Other Writings. Edited by Keith Ansell-Pearson. Translated by Carol Diethe. Cambridge: Cambridge University Press, 2007.

Pippin, Robert. "Morality as Psychology, Psychology as Morality: Nietzsche, Eros, and Clumsy Lovers." In Idealism as Modernism: Hegelian Variations, 35 I-7I. Cambridge: Cambridge University Press, I997. ["Morality as Psychology"]

. "Truth and Lies in the Early Nietzsche." In Idealism as Modernism: Hegelian Variations, 3 I I-29. Cambridge: Cambridge University Press, I997.

Poellner, Peter. Nietzsche and Metaphysics. Oxford: Oxford University Press, I995. 
Reginster, Bernard. The Affirmation of Life: Nietzsche on Overcoming Nihilism. Cambridge, MA: Harvard University Press, 2006. [The Affirmation of Life]

. "What is a Free Spirit? Nietzsche on Fanaticism." Archiv für Geschichte der Philosophie 85 (2003): 5 I-8 5. ["What is a Free Spirit?"]

Richardson, John. Nietzsche's System. Oxford: Oxford University Press, I996.

Ridley, Aaron. Nietzsche's Conscience: Six Character Studies from the "Genealogy". Ithaca, NY: Cornell University Press, I998. [Nietzsche's Conscience]

Rorty, Richard. "Is Truth a Goal of Enquiry? Davidson vs. Wright." The Philosophical Quarterly 45 (I995): 28I-300. ["Is Truth a Goal?"]

Schopenhauer, Arthur. The World as Will and Representation. Translated by E. F. J. Payne. 2 vols. New York: Dover Publications, I969.

Velleman, J. David. "The Possibility of Practical Reason.” Ethics Io6 (I996): 694-726.

Williams, Bernard. Truth and Truthfulness. Cambridge: Cambridge University Press, 2002.

. "Unbearable Suffering". In The Sense of the Past, edited by Miles Burnyeat, 33 I-37. Princeton, NJ: Princeton University Press, 2006

Wittgenstein, Ludwig. Culture and Value. Translated by Peter Winch. Chicago: University of Chicago Press, I980.

Wright, Crispin. Truth and Objectivity. Cambridge: Cambridge University Press, I992. 